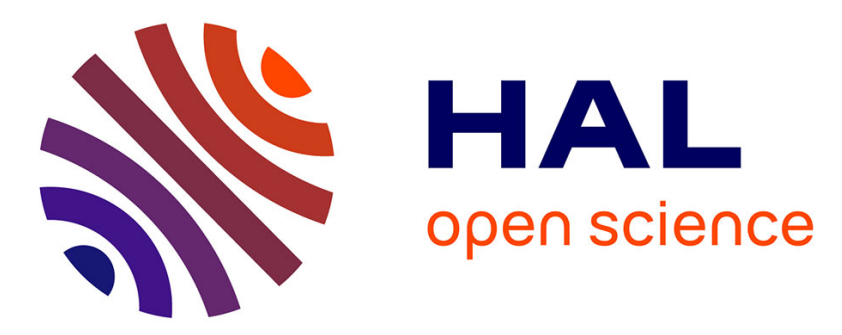

\title{
Effects of underfeeding Awassi ewes in late pregnancy and early lactation on body weight changes and milk production
}

\author{
A El Awad, Av Goodchild, O Gürsoy
}

\section{- To cite this version:}

A El Awad, Av Goodchild, O Gürsoy. Effects of underfeeding Awassi ewes in late pregnancy and early lactation on body weight changes and milk production. Annales de zootechnie, 1995, 44 (Suppl1), pp.319-319. hal-00889476

\section{HAL Id: hal-00889476 https://hal.science/hal-00889476}

Submitted on 1 Jan 1995

HAL is a multi-disciplinary open access archive for the deposit and dissemination of scientific research documents, whether they are published or not. The documents may come from teaching and research institutions in France or abroad, or from public or private research centers.
L'archive ouverte pluridisciplinaire HAL, est destinée au dépôt et à la diffusion de documents scientifiques de niveau recherche, publiés ou non, émanant des établissements d'enseignement et de recherche français ou étrangers, des laboratoires publics ou privés. 


\title{
Effects of underfeeding Awassi ewes in late pregnancy and early lactation on body weight changes and milk production
}

\author{
A El Awad 1, AV Goodchild 1, O Gürsoy 2 \\ 1/International Center for Agricultural Research in Dry Areas, PO Box 5466, Aleppo, Syria ; 2Zootekni Bölümü, \\ Ziraat Fakültesi, Cukurova University, 01330 Adana, Turkey
}

In the Middle East and parts of Turkey, Awassi sheep traditionally graze rangeland for most of the year, and lambing is spread throughout the winter. Late pregnancy and early lactation occur when grazing is limiting. As a consequence sheep are fed straw, cereal grains and other supplements. It is difficult to feed according to requirements during pregnancy, and sheep often have to mobilize body reserves. In countries where there is pressure on land and feed grain is imported, farmers are increasingly feeding low-roughage high-grain winter diets.

We conducted a factorial experiment with 48 individually-penned ewes to compare responses to recent AFRC (1993) allowances, with responses to four types of underfeeding that farmers tend to employ: (F1) feeding for maternal body weight loss in the last 3 weeks of pregnancy ; (F2) feeding so as to mobilize energy reserves in early lactation; (F3) feeding a reduced level of protein (similar to the older ARC (1984) allowances) in both early and midlactation ; and (F4) feeding a low-roughage diet (calculated to provide $12 \mathrm{MJ}$ of metabolisable energy (ME) per $\mathrm{kg} D M$ ) in mid-lactation. Rations included cottonseed cake, barley, barley straw and minerals, and a single changeover design for $\mathrm{F} 4$ was used in midlactation.

The ewes suckled a lamb for 42 days, and hand milking was started gradually from day 29. Important or statistically significant details of performance are shown in table. Underfeeding in late pregnancy (F1) had no lasting effect on lamb or ewe. The reduction in energy level in early lactation (F2) was equivalent to feeding $330 \mathrm{~g}$ less barley daily. It resulted in a smaller body weight loss than was planned and a $90 \mathrm{~g} /$ day reduction in milk yield; the difference in milk yield did not significantly persist into mid-lactation. The high-fibre diet (F4 control) contained 43-57\% straw and increased the volume of milk by $10 \%$ and milk fat yield by $25 \%$. Our results confirm the Awassi's tolerance to underfeeding energy or protein and emphasise the value of roughage in lactation.

\begin{tabular}{|c|c|c|c|c|c|}
\hline \multicolumn{2}{|l|}{ Type of underfeeding } & \multicolumn{2}{|c|}{ Level of feeding } & \multirow{2}{*}{$\begin{array}{c}\text { SE of } \\
\text { difference }\end{array}$} & \multirow{2}{*}{$\begin{array}{c}\text { Significance } \\
\text { probability }\end{array}$} \\
\hline & Effect observed & Requirement & Underfed & & \\
\hline \multicolumn{6}{|c|}{ F1: Fed for maternal body weight loss in last 3 weeks of pregnancy } \\
\hline Days -24 to -3 & Body weight gain $(\mathrm{kg})$ & 2.70 & 0.67 & 0.460 & 0.0001 \\
\hline Days $18-59$ & Body weight loss $(\mathrm{kg})$ & -2.97 & -1.48 & 0.494 & 0.0046 \\
\hline Days $0-42$ & Lamb growth (g/day) & 262 & 247 & 8.8 & 0.093 \\
\hline Days $46-59$ & Milk yield (g/day) & 838 & 773 & 54.2 & 0.24 \\
\hline \multicolumn{6}{|c|}{ F2 : Fed for $0.15 \mathrm{~kg} / \mathrm{d}$ body weight loss (assuming constant milk yield) on days $18-59$} \\
\hline Days $18-59$ & Dietary ME (MJ/day) & 14.9 & 10.8 & & \\
\hline Days $18-42$ & Lamb growth (g/day) & 236 & 212 & 9.3 & 0.014 \\
\hline Days $18-59$ & Body weight loss $(\mathrm{kg})$ & -1.29 & -3.16 & 0.474 & 0.0003 \\
\hline Days $46-59$ & Milk yield (g/day) & 862 & 749 & 52.9 & 0.039 \\
\hline \multicolumn{6}{|c|}{ F3: Fed ARC rather than AFRC protein levels on days $18-101$} \\
\hline Days 18-101 & Dietary protein $(\mathrm{g} / \mathrm{kg} \mathrm{DM})$ & 170.6 & 136.8 & & \\
\hline Days $46-59$ & Milk yield ( $g /$ day) & 831 & 780 & 52.7 & 0.34 \\
\hline \multirow[t]{2}{*}{ Days $60-101$} & Milk yield (g/day) & 510 & 477 & 50.9 & 0.52 \\
\hline & Milk protein (g/litre) & 51.81 & 50.44 & 0.885 & 0.13 \\
\hline \multicolumn{6}{|c|}{ F4: Fed a low-fibre diet (ca $10 \%$ straw) on days 60-101 (change-over on day 81) } \\
\hline Days $60-80$ & Milk yield (g/day) & 541 & 485 & 33.4 & 0.11 \\
\hline Days 81-101 & Milk yield (g/day) & 373 & 346 & 18.4 & 0.16 \\
\hline \multirow[t]{3}{*}{ Days 60-101 } & Milk fat ( $g /$ /itre) & 73.4 & 64.5 & 1.05 & 0.0001 \\
\hline & Milk protein ( $g / l i t r e)$ & 50.93 & 52.24 & 0.396 & 0.0028 \\
\hline & Milk solids (g/litre) & 178.6 & 169.4 & 1.24 & 0.0001 \\
\hline
\end{tabular}

